\title{
$\begin{array}{ll}\text { Research Square } & \text { Preprints are preliminary reports that have not undergone peer review. } \\ \text { They should not be considered conclusive, used to inform clinical practice, } \\ \text { or referenced by the media as validated information. }\end{array}$
}

\section{A Systematic Review of Enteral Feeding by Nasogastric Tube in Young People with Eating Disorders}

\author{
Kristen Hindley ( $\sim$ kristen.hindley@sky.com ) \\ https://orcid.org/0000-0002-0001-5056 \\ Clare Fenton \\ Leeds and York Partnership NHS Foundation Trust \\ Jennifer McIntosh \\ Leeds and York Partnership NHS Foundation Trust
}

University of Manchester School of Medicine: The University of Manchester Faculty of Biology Medicine and Health

Research article

Keywords: nasogastric, enteral feeding, restrictive, eating disorders, young people, adolescents, inpatient

Posted Date: February 18th, 2021

DOI: https://doi.org/10.21203/rs.3.rs-121006/v2

License: @ (1) This work is licensed under a Creative Commons Attribution 4.0 International License. Read Full License

Version of Record: A version of this preprint was published at Journal of Eating Disorders on July 22nd, 2021. See the published version at https://doi.org/10.1186/s40337-021-00445-1. 


\section{Abstract}

Background

Adolescents with severe restrictive eating disorders often require enteral feeding to provide lifesaving treatment.

Nasogastric feeding (NGF) is a method of enteral nutrition often used in inpatient settings to treat medical instability, to supplement minimal oral intake or to boost nutritional intake. This systematic review sets out to describe current practice for NGF.

\section{Methods}

A systematic review following PRISMA guidelines was conducted by searching AMED, EMBASE and MEDLINE databases from 2000-2020. Inclusion terms were: enteral feeding by nasogastric tube, under 18 years, eating disorders, and primary research. Exclusion terms: mental disorders other than eating disorders; non-primary research; no outcomes specific to NG feeding and over 18 years. Titles and abstracts were screened by all authors before reviewing full length articles. Quality assessment, including risk of bias, was conducted by all authors.

Results

29 studies met the full criteria. $86 \%$ of studies were deemed high or medium risk of bias due to the type of study: $34.4 \%$ retrospective cohort and $10.3 \%$ RCT; $17.2 \%$ were qualitative. Studies identified 1) a wide range of practices in different countries, settings, and the reason for initiation; 2) In the UK, standard practice is to introduce NGF if either oral intake is not met or patients are medically unstable; 3 ) NGF may enable greater initial weight gain due to increased caloric intake; 4 ) there are 3 main types of feeding regime: continuous, nocturnal and bolus; 5) high calorie feeds are not typically associated with increased risk of refeeding syndrome; 6 ) complications included nasal irritation, epistaxis, electrolyte disturbance, distress and tube removal; 7) length of stay in hospital is dependent on reason of initiating NGF; 8) psychiatric and medical wards differ in approach; 9) concurrent therapy is often used to facilitate NGF.

\section{Conclusions}

NGF is currently often implemented in specialist settings where oral intake has been refused or insufficient, in hospital due to medical instability, nocturnally to supplement day-time oral intake, or continuously as standard protocol. Due to high risk of bias as a result of the nature of the studies conducted in adolescents with ED, recommendations for clinical practice cannot yet be justified.

\section{Plain English Summary}

Young people with eating disorders often restrict dietary intake to a degree which is detrimental to their physical health. During UK inpatient admission, dietary intake is usually encouraged however occasionally the patient may either continue to decline food, or be in a condition requiring more intensive intervention. In these circumstances, a nasogastric (NG) tube may be placed from nose to stomach to pass nutrition. This systematic review sets out to review the current reported evidence of NG in young people. Results have shown that NG feeding may be administered through different methods such as continuously, multiple single meals (bolus), or overnight to supplement day-time oral intake. Routine NG feeding may allow greater initial caloric intake, which does not increase risk of medical complications, and may actually increase initial weight gain thus reducing time in hospital. NG feeding is used commonly in the hospital setting to treat medical instability as a result of severe malnourishment, and in the specialist ED unit due to failure to meet oral intake. Differences may be due to variable expertise of staff. Side effects are minimal but may include nasal bleeding or irritation, and imbalances in blood electrolytes which can be reduced by providing supplementation.

\section{Background}

There are currently over 700,000 individuals in the UK with an eating disorder (ED) ${ }^{1}$. EDs usually manifest prior to adulthood, with an average age of onset of approximately 15 years, although this is decreasing; with new research from NICE demonstrating that incidence in children aged 12 and under had increased between 2005-2015 in the UK. 2,3 Patients with restrictive eating disorders, including anorexia nervosa (AN), bulimia nervosa (BN) and eating disorder not otherwise specified (EDNOS), are predominantly female (91\%) and Caucasian (92\%), with incidence being approximately 0.014 for females. ${ }^{3}$ Compared to other mental illnesses, EDs have a high mortality rate with young people (YP) with anorexia nervosa (AN) on average 6-10 times more likely to die than the general population. ${ }^{4,5}$ Death is often caused by cardiac abnormalities associated with extremely low bodyweight. ${ }^{6}$ For this reason, acute medical intervention is often warranted in order to reduce mortality. Nasogastric (NG) feeding use in YP with ED is generally seen as a "last resort" to provide lifesaving 
treatment. ${ }^{7,8}$ However, refeeding is a critical component to recovery and NG feeding will often be utilised if a YP has been unable to manage oral intake. 9,10

NG feeding involves a fine bore tube passed via the nasal passage into the stomach in order to administer nutrition. There is a low risk of complications associated with NG feeding if staff receive adequate training and protocols are enforced to ensure that the tube has been passed correctly. ${ }^{11}$ Different methods of NG may be utilised safely, with NG feeds often given as large bolus, continuously through a pump or overnight in order to supplement daytime oral intake. ${ }^{12,13}$ Recent guidance from the British Dietetic Association ${ }^{14}$ for NG feeding under restraint advised 1-2 bolus feeds per day even in those with high risk of refeeding syndrome (RS); it also concluded further research into this area was required. The National Institute for Clinical Excellence has produced guidance for providing nutrition recommending a graded approach. ${ }^{19}$ Neither of these guidelines are specific for young people.

Most EDs will be treated in an outpatient setting with hospitalisation generally reserved for those with severe malnutrition resulting in physical symptoms such as bradycardia, hypotension or dehydration as set out in the MARSIPAN guidance. ${ }^{15}$ Research on NG feeding in YP has tended to focus on the acute refeeding phase in paediatric or psychiatric wards to reduce the risk of RS. ${ }^{16}$ RS can manifest as hypophosphatemia (HP), hypomagnesemia, hypokalemia and other electrolyte imbalances that result in cardiac arrhythmias, seizures and in some cases sudden death. ${ }^{17}$ During the acute refeeding phase the need for weight restoration must be balanced against the risk of developing RS. In practice, most patients (96\%) however present less severely with serum hypophosphataemia and no clinical signs. ${ }^{18}$ Although there is a significant body of research into this, the role of NG feeding remains ill-defined. ${ }^{16}$

Moreover, there is currently conflicting guidance on how to manage NG feeding in YP with ED, in particular how and when to transition between oral and NG feeding. ${ }^{20,21}$ This has resulted in a variety of NG feeding practices across different settings, with many medical wards tending to provide continuous NG feeds and cease oral intake in order to medically stabilise the patient; $20,22-26$, in contrast mental health wards may be more likely to use syringe bolus feeds to provide food when meals are refused, thus encouraging oral intake and aiding normalisation of eating. ${ }^{9,17,27-31}$ This is further supported in a systematic review ${ }^{32}$ whereby $9 / 10$ studies in hospitalised ED patients are given continuous or overnight supplemental NG feeding.

Previous reviews ${ }^{32,33}$ have examined use of NG feeding in ED, including the safety and efficacy of NG feeding as well as short-term and long-term outcomes. However, this will be the first systematic review on the use of NG feeding specifically in YP with ED. Due to the anticipated paucity of studies in this area any research where a meaningful conclusion or result can be drawn regarding NG use in YP with ED will be included. This review aims to examine NG feeding outcomes for patients and its impact on staff, it's effect on length of stay in hospital, complications and factors affecting NG implementation in patients. The use of NG primarily for medical stabilisation will be compared to its use in the psychiatric treatment of YP with ED where possible, and when this is not stated in the study, the setting (medical ward or psychiatric ward) will be utilised to give an indication. The different types of feeding technique (for example bolus and continuous feeds) will be analysed, and any indications given about how and when to commence or cease NG feeding.

\section{Methods}

A comprehensive database search of AMED, EMBASE, APA Psychinfo and MEDLINE was performed with no language restriction from January 2000 to July 2020. Search strategies combined keywords with controlled vocabulary terms (MeSH, Thesaurus); both quantitative and qualitative research were included. The search criteria was peer reviewed by a researcher from the University of York's Child and Adolescent Mental Health Intervention Centre. References were exported and duplicates were removed using the title and abstract.

\subsection{Screening for Eligible Studies}

The full search is available in Appendix 1. The inclusion criteria were: NG feeding, under 18 years, eating disorders, published since 2000 and primary research. The outcomes of interest were: Opinions of YP and staff using NG, amount of YP requiring NG, any interventions that impacted on NG feeding, complications of NG feeding, interventions to mitigate the complications, the setting (medical ward, psychiatric ward or outpatient), the NG method and whether this changed when restraint was required. The exclusion criteria included: No ability to discern results specific to NG feeding, mental disorders other than eating disorders being the focus, where the results do not focus on YP under 18 or it is impossible to separate results for adults from YP, reviews or other non-primary research and research published before 2000 . 
Studies published in languages other than English were translated prior to being reviewed. The PRISMA flowchart was used (Figure 1). Abstracts identified from the initial search were screened in a secondary review process, and full text papers were obtained of those meeting the inclusion criteria or where there was uncertainty. One article published prior to 2000 was included in the full text review due to it requiring translation prior to assessing it against the criteria. Key studies were manually reviewed for additional research, but none were identified that were not already included. There was no disagreement between $\mathrm{CF}$ and $\mathrm{KH}$ who assessed which studies were included.

\subsection{Assessing Study Quality}

There is no validated method to assess the retrospective and qualitative nature of studies included therefore we could not conduct a formal quality assessment or statistical method to evaluate the results. The risk of bias was estimated into high, medium or low using an adapted version of the Agency for Healthcare Research and Quality risk of bias tool as described in Myers ${ }^{34}$ which included an assessment of the bias in the selection of participants, sample size, tools used to assess change and whether the study involved blinding. The studies were analysed for risk of bias independently by $\mathrm{CF}, \mathrm{KH}$ and JM. The risk of bias was deemed to be medium or high (see Table 1) for the majority of the studies included due to the nature of their design, being case series or retrospective cohort studies. Studies included and imperative data can be visualised in Table 2.

\section{Results}

\subsection{Prevalence and Epidemiology}

In 13 studies in which NG was not implemented as standard protocol for all patients, the amount of ED YP administered NG feeding was between $6 \%-66 \% .9,17,28,29,31,35-37,41-11,47$ Other studies implemented NG feeding as standard practice. ${ }^{21-23,26,39}$ YP were often admitted to hospital for medical instability 9,17,22,28,39,23,20,47,25 with medical instability being treated using NG either continuously or for sustained periods of time. $22,44,23,20,24,25,26$ In other cases, NG was implemented due to acute refusal of food or inability to meet oral intake. ${ }^{43,9,10,17,28,31}$ According to Maginot and colleagues ${ }^{17}$ NG was more likely to be required in severely malnourished patients where patients were treated by NG due to inability to manage oral intake in hospital. O'Connor and colleagues ${ }^{31}$ detected no correlation with high calorie initial feeding plans and increased use of NG feeding, where NG was implemented due to recommended oral intake not being met. Nehring and colleagues ${ }^{37}$ found that NG feeding was more likely to be required in: patients of a lower age at admission (14.3 compared to 15.3 years old, $P<0.05)$, those with a shorter time period between disease onset and admission to hospital $(P<0.0001)$, and longer time since last discharge $(P<0.05)$. The reasons for initiating NG feeding are not discussed in this article. NG feeding is prescribed more commonly in Early onset (EO) AN than adult onset $(20 \%$ compared to $0 \%, \mathrm{P}<0.05)$ in a female epidemiological study. ${ }^{43}$ Clausen ${ }^{46}$ described NG as the most frequently used involuntary measure in psychiatric practice and is most commonly used in 15-17 year olds. Bayes and colleagues ${ }^{47}$ indicated that male requirements for NG are similar to those of females from a case report of 10 patients (high bias risk).

\subsection{Setting}

3 studies ${ }^{27,28,36}$ reviewed NG treatment for YP in different settings (one of which was high risk of bias ${ }^{28}$ ). Fuller and colleagues ${ }^{27}$ demonstrated discrepancies in treatment provided to YP in different settings with specialist ED units being less likely to use pumps to deliver continuous feeds, tending to give bolus feeds of higher volume. This may be due to difference in staff ability, resources available or differences in treatments between mental health $(\mathrm{MH})$ and medical settings. Akgul and colleagues ${ }^{36}$ (Turkey) concluded a general paediatric ward was a viable alternative for treatment (including NG) of YP with medical instability as a result of ED when specialist mental health ward admission is not possible. Specialist ED units were superior due to expertise of staff and resources available. Street et $\mathrm{al}^{28}$ (UK) showed that patients admitted to a paediatric ward due to medical instability who were given NG due to acute refusal of oral intake may benefit from joint child and adolescent MH services (CAMHS) and paediatric input. These studies highlight that a MH ward with expertise in ED, where available, may be beneficial for treatment of ED requiring NG feeds compared to a medical ward setting if the YP is medically stable.

Almost all studies reporting initial weight gain were in a medical ward setting apart from Silber et $\mathrm{al}^{21}$ which was in a MH ward setting (and is high risk of bias). Studies focusing on refeeding protocols and daily calorie intake were mainly conducted in medical ward settings 9,17,22,24,31 (Table 3). Studies focusing on patient and staff experience of NG feeding ${ }^{40,45,48}$ were set in a MH setting apart from Neiderman and colleagues. ${ }^{40}$

This review detected that the majority of studies were conducted in affluent countries with a Caucasian majority. There were no studies from Asia, South America or Africa. In the UK three studies described NG use when there is a medical need for nutrition after oral intake is 
refused $27,28,40$ or oral diet does not fully meet the nutritional needs. ${ }^{31}$ Neiderman et al ${ }^{38}$ case reports (high risk of bias) described instances where 4 patients received NG due to medical instability. Falcoski et al ${ }^{30}$ (high risk of bias) also described 3 cases, representative of a larger group, where NG was used to manage medical instability. A similar approach was found in studies from Germany ${ }^{37,43}$ and Turkey. ${ }^{35,36}$ In Australian based studies, NG was given due to refusal of oral intake in two studies ${ }^{9,10}$ as well as to treat medical instability. ${ }^{26,47} \mathrm{~A}$ retrospective cohort study ${ }^{24}$ compared NG given continuously or as a nocturnal supplement with oral intake. Studies from North America also focused on medical instability for NG use. ${ }^{17,21,39,41}$

\subsection{Reported Initial Weight Gain}

Agostino et al study ${ }^{23}$ compared a higher calorie (1200-2000kcal) continuous NG fed cohort to lower calorie (800-1500kcal) oral intake; results showed greater initial weight gain in NG fed cohort with oral intake body mass change by -2.9 to $+2.6 \mathrm{~kg}$ average in the first week in the oral intake group. $51 \%$ patients in oral group lost or made no change to weight in first week. This was only $6 \%$ in NG fed cohort. There was no significant difference in groups baseline at the start. There was also greater weight gain in nocturnal NG refeeding than oral intake alone in Silber et al study ${ }^{21}$ (high risk of bias) where all male AN patients after a specific date received nocturnal NG feeding as standard practice.

O'Connor et al (UK) study ${ }^{31}$ examined the effects of a higher calorie refeeding protocol compared to standard protocol; it showed that calorie intake as low as $1200 \mathrm{kcal}$ per day did not cause any initial reduction in body weight. NGF was routinely used to supplement oral intake in this study. Madden et $\mathrm{al}^{25}$ (Australia) prescribed higher than standard protocol initial calories using routine continuous NG feeding aiming for 2400-3000kcal per day and did not identify any initial drop in weight of patients.

\subsection{Patient and Staff Experience of Nasogastric Feeding}

4 studies used qualitative methods to analyse patient, parent and professional opinions on NG feeding. ${ }^{10,40,45,48}$ Nursing assistant's views centred around: NG being an unpleasant practice, becoming sensitized or desensitized, and the importance of developing coping mechanisms to manage the distress. Assaults on nursing assistants were also described (in a study with high risk of bias), such as head butting, hitting and abuse as a result of restraining patients during NG feeding ${ }^{48} 82 \%$ of Dietitians considered NG feeding a necessary procedure if oral diet is inadequate. ${ }^{10}$

YP viewed being NG fed as: an unpleasant experience, a necessary intervention, a psychological signifier of illness, and an emphasis in an underlying struggle for control by Halse and colleagues. ${ }^{45}$ Some described NG feeds as easier than eating as it "disguised" the amount due to no swallowing; others felt it was a form of punishment for not gaining enough weight. YP described manipulating the tube or syringing out the feed to prevent weight gain. Others found NG feeding a helpful motivator for oral intake. ${ }^{40}$ Neiderman and colleagues $^{40}$ (high risk of bias) found $71 \%$ of YP in the study did not consent to being NG fed and $66 \%$ had to be restrained to NG feed, however later in their treatment many reflected that they understood the necessity of the procedure. Conversely the YP in Paccagnella and colleagues $^{20}$ research stated NG was helpful, particularly initially when an oral diet was challenging to manage.

\subsection{Feeding Regime and Calorie Intake}

A variety of different feeding regimes were identified in this review which are summarised in Table 3 . Refeeding protocols daily calorie intake varied greatly between studies particularly as many studies were evaluating the outcome of higher calorie refeeding protocols. $9,17,22,24,31$ Most studies tailored the calorie requirements to the individual patient, accounting for initial weight for height percentage and signs of medical instability. The majority commenced on daily intake of less than $2000 \mathrm{kcal}$ and increased periodically.

\subsection{Nutritional Information of Enteral Nutrition Administered via Nasogastric Tube}

Only 5 studies reported on the nutritional content of feeds in the review. ${ }^{17,20,23-25}$ YP in the NG cohort in Maginot and colleagues ${ }^{17}$ and Agostino and colleagues ${ }^{23}$ were supplied with a formulation containing $44 \%$ carbohydrate. In Paccagnella and colleagues ${ }^{20}$ all YP displaying signs of medical instability were commenced on solely NG feeding again using a formulation containing $44 \%$ carbohydrate with $19.7 \%$ protein and $36 \%$ lipids. Madden et al ${ }^{25}$ described NG feeds containing $30 \%$ fats and less than $50 \%$ carbs. NG formula used in Parker et al ${ }^{24}$ commenced at $1 \mathrm{kcal} / \mathrm{mL}$, however $1.5 \mathrm{kcal} / \mathrm{mL}$ and $2 \mathrm{kcal} / \mathrm{mL}$ formulae were also used in order to increase total calorie intake. Dietary intake could also be supplemented with oral nutrition supplement drinks at 300-400kcal each. ${ }^{24} 15 / 17$ dietitians stated that they used vitamin and mineral supplementation prophylactically or therapeutically, More than $33 \%$ Australian dieticians reported that they administered this regardless of risk of refeeding syndrome in a cross sectional study. ${ }^{10}$ 
Complications associated with NG feeding found in this review are summarised in Table 3, with the most frequently described being nasal irritation or epistaxis, anxiety related to the procedure and electrolyte disturbance (which occurred with both oral and NG refeeding). Overall, this review found 5 studies $^{9,17,23,24,29}$ reported some incidence of electrolyte disturbance, 3 studies ${ }^{21,29,39}$ described epistaxis and 2 studies ${ }^{39,40}$ described behavioural problems associated with the procedure. No study reported a YP developed RS and Nehring and colleagues ${ }^{37}$ concluded that NG feeding had no impact on growth, recovery or presence of psychiatric co-morbidities.

Kezelman and colleagues (Australia) $2018^{26}$ used validated measures of anxiety and depression to assess the impact of these symptoms and core ED symptoms on weight restoration, using NG in adjunct to oral intake as part of a rapid refeeding regime. During admission symptoms reduced but this was not attributed to weight restoration in itself suggesting a high calorie rapid refeeding schedule would not exacerbate or ameliorate ED and other psychiatric symptoms.

\subsection{Length of Time Receiving NG feeding}

Agostino and colleagues ${ }^{23}$ delivered nutrition on a medical ward solely via NG for 14 days before commencing oral diet in addition to NG feeding. The average length of time on NG feeding in this study was 20.7 days; NG was terminated as YP accepted more than $50 \%$ oral caloric quota compared to theoretical reported quota. Madden et al ${ }^{22}$ determined the duration of NG feeding was a minimum of 14 days,

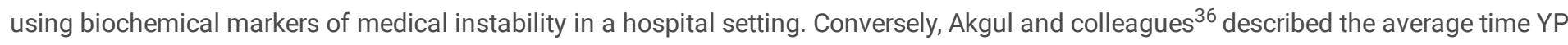
required NG feeding as only 2.5 days before transitioning to an oral diet, where NG feeds are delivered on a hospital ward due to medical instability (Turkey).

\subsection{Length of Stay Associated with NG Feeding}

Length of stay was reported in studies from medical and $\mathrm{MH}$ ward settings, however, the specific package of treatment YP received in each study was different depending on the country of origin. For example, in Australian studies medical wards tended to include high levels of psychiatric treatment alongside medical treatment. ${ }^{26}$ Any hospital admission was significantly longer $(P<0.0001)$ for a YP requiring NG feeding compared to those managing an oral diet in a German retrospective cohort study. ${ }^{37}$ However, this study does not discuss the reasons NG was implemented. Silber and colleagues ${ }^{21}$ highlighted that supplemental overnight NG feeding was associated with a shorter length of stay (LOS) for medical stabilisation, than those YP consuming oral intake alone (36 days compared to 39.9 days). Agostino and colleagues $^{23}$ supported this, demonstrating that YP on medical wards having NG feeds had a mean LOS of 33.8 days compared to those in the same setting having an oral diet who had a mean of 50.9 days, however, the oral diet was lower in calories therefore taking longer for weight recovery and medical stabilisation.

Strik Lievers and colleagues ${ }^{44}$ concluded that factors affecting LOS on a psychiatric ward included duration of AN, need for intensive care, adherence to oral intake, presence of a comorbidity, and requirement for NG feeding when NG was implemented due to medical instability. In this study the mean LOS was significantly increased: 117 days for YP managing oral intake compared to 180 days for those requiring NG. They concluded that the requirement for NG was an indication of severity and resistance to oral feeding ${ }^{44}$ Maginot et al study ${ }^{17}$ in a medical ward (where NG was implemented due to insufficient oral intake) suggested that NG feeding was used for YP with more severe medical problems, (such as intractable vomiting and superior mesenteric artery syndrome) and therefore took longer to transition to oral diet resulting in a longer admission.

\subsection{Concurrent Therapy in Adjunct to Nasogastric Feeding}

6 studies ${ }^{17,22,26,29,38,39}$ discussed therapy as an adjunct to refeeding. In Madden and colleagues ${ }^{25}$ YP participated in family-based therapy (FBT) during their admission. Couturier and Mahmood ${ }^{29}$ (psychiatric unit, Canada) highlighted that meal support therapy reduced the requirement for NG feeding from $66.7 \%$ to $11.1 \%$, criteria for NG feeding was the same in both groups throughout and oral intake was 
encouraged. In Robb and colleagues study ${ }^{39}$ YP were provided with meal support, planned group activities, daily group therapy, individual therapy, FBT three times per week, and expressive therapy twice per week (NG delivered using supplementary nocturnal feeds). Gusella and colleagues ${ }^{41}$ (Canada) compared parent led therapy (PLT) to non-specific therapy (psychologist led talking therapy). PLT was based on FBT and included parents reducing child exercise and increasing oral intake. Results demonstrated that YP receiving PLT had a significantly reduced requirement for NG $(P<0.05)$ (setting and indication for NG feeding not discussed). Maginot and $\operatorname{colleagues}^{17}$ (USA) concluded that YP receiving NG often required behavioural interventions in the acute refeeding phase to manage the refusal of oral intake. Patients in this study were fed via NG if oral intake was refused. Kezelman et al ${ }^{26}$ (Australia) described regular group therapy with an occupational therapist (OT) as well as a psychologist, and physiotherapy during nutritional rehabilitation with continuous followed by supplemental nocturnal NG feeds.

\section{Discussion}

There are a number of limitations to the conclusions that can be drawn from this review. The majority of studies included were retrospective and based around case note reviews which are subjective and therefore likely to be biased. A retrospective design also creates selection bias as those lost to follow up are not considered. Bias can also occur due to the different treatment groups being recorded at different times thus confounding variables may include different staff working at the setting and different methods of treating YP. Only $52 \%$ of studies were conducted prospectively. 3 studies were qualitative interview studies, examining patient or staff feelings towards NG feeding in practice which increases the risk of confirmation bias. The majority also had a relatively small sample size, again introducing the possibility of bias and reducing generalizability. $58 \%$ of the studies included only examined the effect of NG feeding as a secondary outcome of their study. It is not possible from these studies to make any comparison between NG feeding and oral intake due to the confounding effect that for the vast majority of studies only high risk, medically unstable YP were considered for NG feeding. Pragmatic, prospective studies that control for this confounder are required for any such comparison to be made.

Studies in this review included both male and female patients. However, out of 25 patient focused studies, most had a female majority, 6 studies ${ }^{20,26,37,39,43,44}$ were conducted on female only cohorts, 2 studies ${ }^{21,47}$ were on male only cohorts. 1 study ${ }^{39}$ included only Caucasian participants however the majority of studies were conducted in affluent, Caucasian countries which limits the generalisability of this review. $31 \%$ of the studies included were set in Australia, interestingly only $14 \%$ were conducted in America. 16 studies included patients with AN only. 9,10,20,21,22,25,29-31,37-39,41,43,44,46

It is evident that there is a wide variety of practices regarding NG feeding in YP with eating disorders globally. ${ }^{9,21,28}$ Most studies identified that between $10-20 \% 9,17,29,43$ of YP admitted to a psychiatric or medical ward for ED treatment required NG, although in some studies this was significantly higher. ${ }^{42,44}$ These figures are from studies where NG is initiated due to either medical instability or inadequate oral intake and not when it is administered routinely. Given that Kodua and colleagues ${ }^{48}$ stated the procedure can be painful for YP and can cause complications, there is an urgent need for research exploring this wide variation in use of NG feeding. A review conducted by Rizzo and colleagues $^{49}$ (2019), which focused on NG for acute refeeding, also found a wide variety of practices. This review supports their finding that, based on current research, it is not possible to determine whether a different NG feeding regime is required when the patient is acutely medically unstable compared to those who are stable but have inadequate oral diet.

From this systematic review it is evident that there are 3 focal methods of NG feeding: continuous, ${ }^{23,25}$ nocturnal, ${ }^{26,28,29}$ and bolus meal replacement. ${ }^{9}$ It is not possible from this review to discern the advantages and disadvantages of each method as no study made a direct comparison. Medical wards used continuous feeding more frequently then $\mathrm{MH}$ wards but this tended to be for a short period of time while the YP was medically unstable, after this they would be transitioned to an oral diet.22,23,25,26 It is probable that medical wards primarily manage YP for short periods to stabilise physical health, while MH wards seek primarily to treat psychological ED symptoms that are preventing the YP from managing an oral diet. This difference could account for the conflicting outcomes from studies on the impact NG has on the LOS. $21,23,44$

Qualitative studies indicated that YP found that they were able to manipulate the feed or tube if it was left in situ when they were not supervised. ${ }^{40} \mathrm{NG}$ feeding under restraint used bolus feeds due to concerns around the tube being removed once restraint had ceased. ${ }^{45}$ There was no indication from studies that continuous or nocturnal feeds had a significant advantage in terms of health risks such as reducing RS, however, they were often utilised in studies when the YP required medical stabilisation. ${ }^{22,25,26}$ Agostino and colleagues ${ }^{23}$ 
found that NG feeding does have the advantage of improving weight restoration compared to oral diet alone, however the calorie content of the NG fed cohort was greater than the oral fed cohort.

No study discussed in detail the strategy used to transition from NG feeds back to an oral diet. Those studies where NG was used for medical stabilisation often described a short period of NG before a quick transition back to an oral diet. ${ }^{22,23,36}$ Studies using bolus feeds stated that oral intake was encouraged and it was only when this was not fully achieved that supplementary NG was used. ${ }^{21,39}$ This appeared to be either after each meal, at set times during the day or once in the evening. ${ }^{27,30}$ For nocturnal feeds, oral diet was encouraged during the day. In most studies the NG feed supplemented any deficit in oral intake but occasionally also provided additional calories above those prescribed in the meal plan. ${ }^{22,25,39}$ In studies where continuous NG was provided, YP were sometimes not given the option of an oral diet so that their calorie intake could be closely monitored. ${ }^{22-24,31}$ These studies discussed ceasing NG feeds after the risk of RS had reduced; most gave a time frame between 2-14 days. ${ }^{24,44}$

The main disadvantage to bolus feeding is that the NG tube requires reinsertion each time a feed is required, however, this should be weighed against the advantages found in this review including reducing the ability for feeds and the tube to be manipulated. ${ }^{40}$ It also provides a tangible motivation to eat the full meal plan provided which should always be encouraged over NG feeding. Further research is required to assess whether there may be some advantages to bolus or nocturnal feeding over continuous NG feeding, which method is the safest and best aids transition back to a fully oral diet.

Similar to the review conducted by Hale and Logomarsino ${ }^{33}$ who found RS to be a rare complication, it is reassuring to find that no study in this review reported YP developing RS despite some studies starting on high calorie NG feeding plans. ${ }^{9,17,24,30,42}$ Although complications such as electrolyte abnormalities did occur there was no evidence that this was attributable to the NG feeding compared to oral diet. 9,17,23,24 The results of this review indicate that high calorie NG feeds can be safely administered and have the advantage of shortening LOS and therefore should be considered for those where adequate monitoring and vitamin or mineral supplementation can be provided. However, further research is required to assess the optimum NG feeding regime for YP at different levels of RS risk.

In two studies intensive meal support and concurrent therapy reduced the number of NG episodes (whereby NG was utilised when oral diet was inadequate) before managing a full oral diet. ${ }^{29,41}$ This could have the advantage of reducing LOS in medically stable YP. Many of the studies based in Australia described significant levels of therapeutic input for YP on medical wards. ${ }^{22,25,26}$ Kezelman and colleagues ${ }^{26}$ described therapeutic input to YP admitted to an Australian medical unit and found a significant reduction in many core ED symptoms which was not attributable to weight restoration in itself. This review would support intensive therapeutic input provided from the start of the admission which, in a medical ward, may require outreach work or a day treatment centre from children's mental health services.

Studies in this review indicated that a number of YP in MH wards required restraint to NG feed with one study reporting this was required for $66 \%$ of YP. ${ }^{24}$ NG under restraint was described as causing significant distress for staff and can risk injury to both staff and YP. ${ }^{48}$ When NG under restraint is required it may be required for a significant duration; in one study ${ }^{46}$ the average was 170 days.

\section{Conclusions}

This review describes the large differences in the use of NG for YP with ED in medical and psychiatric wards in a number of countries across the globe. NG feeding is an important aspect of treatment for YP with ED who are medically unstable or are unable to manage an oral diet. Due to the high level of bias in the studies, we are unable to make recommendations for clinical practice from this review. This review starkly highlights the lack of high quality evidence around the use of NG feeding in ED YP and the need to develop a robust global consensus on the type of NG, feed quantity, use of restraint, weaning technique and support needed for the YP and their family while NG is required.

\section{Abbreviations}




\begin{tabular}{|c|c|}
\hline$\%$ IBW & percentage ideal body weight \\
\hline AN & anorexia nervosa \\
\hline AOED & adolescent onset eating disorder \\
\hline CAMHS & child and adolescent mental health service \\
\hline ED & eating disorder \\
\hline EOED & early onset eating disorder \\
\hline FBT & family-based therapy \\
\hline HP & hypophosphataemia \\
\hline LOS & length of stay \\
\hline $\mathrm{MH}$ & mental health \\
\hline$N G(F)$ & nasogastric (feeding) \\
\hline OT & occupational therapist \\
\hline PLT & parent led therapy \\
\hline PRISMA & Preferred Reporting Items for Systematic Reviews and Meta-Analyses \\
\hline RDI & recommended daily intake \\
\hline RS & refeeding syndrome \\
\hline YP & young person/people \\
\hline
\end{tabular}

\section{Declarations}

Ethical Approval and Consent to Participate: No ethical approval or consent to participate required due to the nature of the study.

Consent for Publication: All authors have reviewed the document and consent to publication.

Availability of Supporting Data: All articles analysed in this study can be found in Table 2 and can be traced back to primary articles using References on Page 16.

Competing Interests: Authors declare no competing interests.

Funding: No funding.

Authors Contributions: KH and CF performed search of databases and created the document. All authors assessed bias risk. KH gathered data and interpreted results. CF performed the discussion. JM was responsible for references.

Acknowledgements: There are no other acknowledgements to be made.

\section{References}

1. National Guideline Alliance (UK). Eating Disorders: Recognition and Treatment. London: National Institute for Health and Care Excellence (UK); 2017 May. (NICE Guideline, No. 69.) Available from: https://www.ncbi.nlm.nih.gov/books/NBK436876/

2. Hay AP, Chinn D, Forbes D, Forbes S, Madden, R Newton, et al.Royal Australian and New Zealand College of Psychiatrists clinical practice guidelines for the treatment of eating disorders. Australian and New Zealand Journal of Psychiatry. $2014 ; 48$ 11:977-1008.

3. Petkova BH, Simic M, Nicholls D, Ford T, Prina AM, Stuart R. Incidence of anorexia nervosa in young people in the UK and Ireland: a national surveillance study. BMJ Open 2019; 9:e027339. doi:10.1136/bmjopen-2018-027339.

4. Roux H, Chapelon E, Godart N. Epidemiology of anorexia nervosa: a review. Encephalitis 2013; 39 2: 85-93. 
5. Birmingham CL, Su J, Hlynsky JA, Goldberg EM, GAO M. The mortality rate from anorexia nervosa. Int J Eat Disord. $2005 ; 38$ 2:143-6. doi: 10.1002/eat.20164

6. Isner JM, Roberts WC, Heymsfield SB, Yager J. Anorexia nervosa and sudden death. Ann Intern Med. 1985;102 (1) :49-52.

7. National Collaborating Centre for Mental Health. Core interventions in the treatment and management of anorexia Nervosa bulimia Nervosa and related eating disorders. London: National Institute for a Clinical Excellence, 2004.

8. American Psychiatric Association. Treatment of patients with eating disorders. America Journal of Psychiatry 2006; 163 (7):4-54.

9. Whitelaw M, Gilbertson H, Lam PY, Sawyer S M. Does aggressive refeeding in hospitalized adolescents with anorexia nervosa result in increased hypophosphatemia? J Adolesc Health 2010;46:577-82.

10. Rocks T, Pelly F, Wilkinson P. Nutritional management of anorexia nervosa in children and adolescent inpatients: The current practice of Australian dietitians. Nutrition \& Dietetics 2014;71:100-107.

11. Earley T. Improving safety with nasogastric tubes: a whole-system approach. Nursing Times 2019;115 (12): 50-51.

12. Best C. How to set up and administer an enteral feed via a nasogastric tube. Nurs Stand 2017; 31 (45):42-47.

13. Ichimaru S. Methods of Enteral Nutrition Administration in Critically III Patients: Continuous, Cyclic, Intermittent, and Bolus Feeding. Nutr Clin Pract2018; 33 (6):790-795.

14. British Dietetic Association. Naso-Gastric Tube Feeding under restraint best practice guidelines for Dietitians July 2019.

15. Royal Collage of Psychiatry. CR168s Summary of Junior Marsipan: Management of really sick patients under 18 with Anorexia Nervosa. 2015.

16. Garber AK, Sawyer SM, Golden NH, et al. A systematic review of approaches to refeeding in patients with anorexia nervosa. Int. J. Eat. Disord. 2016;49: 293-310.

17. Maginot TR, Kumar M M, Shiels J, Kaya W, Rhee KE. Outcomes of an inpatient refeeding protocol in youth with anorexia nervosa: Rady Children's Hospital San Diego/University of California, San Diego. Journal of eating disorders 2017;5 (1):1-10.

18. Skipper. Refeeding syndrome or refeeding hypophosphatemia: a systematic review of cases. Nutr Clin Pract 2012; 27 1:34-40.

19. NICE. Nutrition support in adults | Quality standards | NICE. 2019. https://www.nice.org.uk/guidance/qs24. June 282019.

20. Paccagnella A, Mauri A, Baruffi C , Berto R, Zago R, Mar, et al. Application criteria of enteral nutrition in patients with anorexia nervosa: correlation between clinical and psychological data in a "lifesaving" treatment. JPEN J Parenter Enteral Nutr 2006;30 (3):231-9.

21. Silber TJ, Robb AS, Orrell-Valente JK, Ellis N, Valadez-Meltzer A, Dadson MJ. Nocturnal nasogastric refeeding for hospitalized adolescent boys with anorexia nervosa. J Dev Behav Pediatr 2004; 25 (6):415-8.

22. Madden S, Miskovic-Wheatley J, Wallis, et al. A randomized controlled trial of in-patient treatment for anorexia nervosa in medically unstable adolescents. Psychol Med 2015;45:415-27.

23. Agostino H, Erdstein J, Di Meglio G. Shifting paradigms: continuous nasogastric feeding with high caloric intakes in anorexia nervosa. J Adolesc Health 2013; 53:590-4.

24. Parker E, Faruquie S, Anderson G, et al.Higher Caloric Refeeding Is Safe in Hospitalised Adolescent Patients with Restrictive Eating Disorders. Journal of Nutrition and Metabolism 2016:1-9.

25. Madden S, Mskovic-Whaetley J, Clarke S, Touyz S, Hay P, Kohn MR. Outcomes of a rapid refeeding protocol in Adolescent Anorexia Nervosa. Journal of Eating Disorders 2015;3:8.

26. Kezelman S, Crosby RD, Rhodes P, Hunt C, Anderson G, Clarke S, Touyz S. Anorexia Nervosa, Anxiety, and the Clinical Implications of Rapid Refeeding, Frontiers in Psychology 2018; 9: P1097

27. Fuller S, Street O, Hudson L, Nicholls D. Enteral feeding young people with anorexia nervosa under restraint in inpatient settings. British Journal of Mental Health Nursing 2019;8:124-128.

28. Street K, Costelloe S, Wooton M, Upton S, Brough J. Structured, supported feeding admissions for restrictive eating disorders on paediatric wards. Arch Dis Child 2016;101:836-8.

29. Couturier J, Mahmood A. Meal support therapy reduces the use of nasogastric feeding for adolescents hospitalized with anorexia nervosa. Eat Disord 2009;17:327-32.

30. Falcoski P, Philpot U, Tan J, Hudson LD, Fuller SJ. Nasogastric tube feeding in line with new dietetic guidelines for the treatment of anorexia nervosa in a specialist children and adolescent inpatient unit: a case series. Journal of Human Nutrition and Dietetics 2020; May.

31. O'Connor G, Nicholls D, Hudson L, Singhal A. Refeeding Low Weight Hospitalized Adolescents With Anorexia Nervosa: A Multicenter Randomized Controlled Trial. 2016 Nutr Clin Pract 2016;31:681-9.

Page $10 / 19$ 
32. Rizo S, Douglas JW, Lawrence JC. Enteral Nutrition via Nasogastric Tube for Refeeding Patients with Anorexia Nervosa: A Systematic Review. Nutr Clin Pract 2019; 34 (3):359-370.

33. Hale D, Logomarsino JV. The use of enteral nutrition in the treatment of eating disorders: a systematic review. Eat Weight Disord 2019; 24 (2):179-198.

34. Myers E, McCrory D, Mills A, et al. Effectiveness of Assisted Reproductive Technology. Evidence Report/Technology Assessment No. 167 (Prepared by the Duke University Evidence-based Practice Center under Contract No. 290-02-0025.) AHRQ Publication No. 08E012. Rockville, MD: Agency for Healthcare Research and Quality; May, 2008

35. Akgul S, Akdemir D.P, Kara M, Derman, O'Cetin FC, Kabbur N. The understanding of risk factors for eating disorders in male adolescents. Int J Adolesc Med Health 2016;28:97-105.

36. Akgul S, Pehlivanturk-Kizilkan M, Ors S, Derman O, Duzceker Y, Kanpur N. Type of setting for the inpatient adolescent with an eating disorder: Are specialized inpatient clinics a must or will the pediatric ward do? Turk J Pediatr 2016; 58:641-649.

37. Nehring I, Kewitz K, Von Kries R, Thyen U. Long-term effects of enteral feeding on growth and mental health in adolescents with anorexia nervosa-results of a retrospective German cohort study. Eur J Clin Nutr 2014; 68:171-177.

38. Neiderman M, Zarody M, Tattersall M, Lask B. Enteric feeding in severe adolescent anorexia nervosa: A report of four cases. Int J Eat Disord 2000; 28:470-475.

39. Robb AS, Silber TJ, Orwell-Valente JK, et al. 2002. Supplemental nocturnal nasogastric refeeding for better short-term outcome in hospitalized adolescent girls with anorexia nervosa. Am J Psychiatry 2002;159:1347-53.

40. Neiderman M, Farley A, Richardson J, Lask B. Nasogastric feeding in children and adolescents with eating disorders: toward good practice. Int J Eat Disord 2001;29:441-8.

41. Gusella JL, Campbell AG, Lalji K. A shift to placing parents in charge: Does it improve weight gain in youth with anorexia? Paediatrics \& child health 2017;22:269-272.

42. Madden S, Morris A, Zurynski YA, Kohn M, Elliot EJ. Burden of eating disorders in 5-13-year-old children in Australia. Med J Aust 2009;190:410-4.

43. Van Noort BM, Lohmar SK, Pfeiffer E, Lehmkul U, Winter SM, Kappel V. Clinical characteristics of early onset anorexia nervosa. Eur Eat Disord Rev 2018;26:519-525.

44. Strik Lievers L, Curt F, Wallier J, et al. Predictive factors of length of inpatient treatment in anorexia nervosa. Eur Child Adolesc Psychiatry 2009;18:75-84.

45. Halse C, Broughtwood D, Clarke S, Honey A, Kohn M, Madden S. Illumating multiple perspectives: meaning of nasogastric feeding in anorexia Nervosa. EuropeonEating Disorders Review 2005;13:264-272.

46. Clausen L, Larsen JT, Bulik CM, Peterson L. A Danish register-based study on involuntary treatment in anorexia nervosa. Int J Eat Disord 2018;51:1213-1222.

47. Bayes A, Madden, S. Early onset eating disorders in male adolescents: a series of 10 inpatients. AustralasPsychiatry 2011;19:526-30.

48. Kodua M, MacKenzie JM, Smyth N. Nursing assistants' experiences of administering manual restraint for compulsory nasogastric feeding of young persons with anorexia nervosa. International Journal of Mental Health Nursing, 2020; June.

49. Rizzo S.M, Douglas JW, Lawrence JC. Enteral Nutrition via Nasogastric Tube for Refeeding Patients With Anorexia Nervosa: A Systematic Review. Nutr Clin Prac 2019;34 (3):359-370.

\section{Appendix}

1. Naso-gastric or nasogastric or *enteric or *enteral or tube

2. (Anorexia or bulimia or eat* or feed*) NOT bowel NOT surgery NOT intestin*

3. (child* or paed* or adolescen* or teen* or young) NOT baby NOT toddler NOT infant NOT animal NOT maternal NOT parental NOT learning disabl* NOT learning disabil*

4. 1 AND 2 AND 3

\section{Tables}

Table 1 Risk of Bias of Studies Included in this Systematic Review of Enteral Feeding by Nasogastric Tube in Young People with Eating Disorders

Page $11 / 19$ 


\begin{tabular}{|c|c|c|c|c|c|c|c|c|c|c|}
\hline Authors & $\begin{array}{c}\text { Study design } \\
\text { RCT }=6 \\
\text { Prospective } / \text { cross } \\
\text { section }=4 \\
\text { Retrospective } \\
\text { cohort }=2 \\
\text { Case series }=0\end{array}$ & $\begin{array}{c}\text { Sample } \\
\text { size }(<100=6 \\
<50=4 \\
<10=2 \\
>10=0)\end{array}$ & $\begin{array}{l}\text { Unbiased } \\
\text { cohort } \\
\text { selection }\end{array}$ & $\begin{array}{c}\text { Selection } \\
\text { minimizes } \\
\text { baseline } \\
\text { differences in } \\
\text { demographic } \\
\text { factors }\end{array}$ & $\begin{array}{c}\text { Sample } \\
\text { size } \\
\text { calculated }\end{array}$ & $\begin{array}{c}\text { Validated } \\
\text { method for } \\
\text { ascertaining } \\
\text { clinical status } \\
\text { or participant } \\
\text { group }\end{array}$ & $\begin{array}{l}\text { Validated } \\
\text { methods for } \\
\text { assessing } \\
\text { variables of } \\
\text { interest }\end{array}$ & $\begin{array}{l}\text { Validated } \\
\text { methods } \\
\text { for } \\
\text { assessing } \\
\text { outcome }\end{array}$ & $\begin{array}{c}\text { Blind } \\
\text { outcome } \\
\text { assessment }\end{array}$ & $\begin{array}{c}\text { Score } \\
0-20= \\
\text { High } \\
\text { risk, } \\
21-40= \\
\text { Medium } \\
\text { risk } \\
>40=\text { Low } \\
\text { risk }\end{array}$ \\
\hline $\begin{array}{l}\text { (Whitelaw et } \\
\text { al., 2010) }\end{array}$ & 2 & 2 & 0 & 0 & 0 & 6 & 6 & 6 & 0 & 22 \\
\hline $\begin{array}{c}\text { (Rocks et al., } \\
2014)^{10} \\
\end{array}$ & 4 & 2 & 2 & 2 & 0 & 6 & 6 & 6 & 0 & 28 \\
\hline $\begin{array}{l}\text { (Maginot et } \\
\text { al., 2017) }\end{array}$ & 2 & 4 & 2 & 2 & 0 & 6 & 6 & 4 & 0 & 26 \\
\hline $\begin{array}{c}\text { (Paccagnella } \\
\text { et al., } \\
2006)^{20} \\
\end{array}$ & 4 & 2 & 0 & 2 & 0 & 6 & 6 & 6 & 0 & 26 \\
\hline $\begin{array}{c}\text { (Silber et al., } \\
2004)^{21} \\
\end{array}$ & 2 & 2 & 0 & 0 & 0 & 6 & 6 & 4 & 0 & 20 \\
\hline $\begin{array}{l}\text { (Madden et } \\
\text { al., 2015b) }\end{array}$ & 6 & 4 & 4 & 4 & 0 & 6 & 6 & 6 & 6 & 42 \\
\hline $\begin{array}{l}\text { (Agostino et } \\
\text { al., 2013) }\end{array}$ & 2 & 6 & 0 & 0 & 6 & 6 & 6 & 6 & 6 & 38 \\
\hline $\begin{array}{c}\text { (Parker et } \\
\text { al., 2016) }\end{array}$ & 2 & 6 & 6 & 0 & 0 & 6 & 6 & 6 & 0 & 32 \\
\hline $\begin{array}{l}\text { (Madden et } \\
\text { al., } 2015 a)^{25}\end{array}$ & 6 & 4 & 6 & 4 & 6 & 6 & 6 & 6 & 6 & 50 \\
\hline $\begin{array}{c}\text { Kezelman et } \\
\text { al } 2018^{26}\end{array}$ & 4 & 2 & 2 & 2 & 0 & 6 & 6 & 6 & 0 & 28 \\
\hline $\begin{array}{c}\text { (Fuller et al., } \\
2019)^{27} \\
\end{array}$ & 4 & 6 & 6 & 6 & 0 & 6 & 6 & 6 & 0 & 40 \\
\hline $\begin{array}{c}\text { (Street et al., } \\
2016)^{28} \\
\end{array}$ & 0 & 2 & 0 & 0 & 0 & 0 & 0 & 6 & 0 & 8 \\
\hline $\begin{array}{l}\text { (Couturier } \\
\text { and } \\
\text { Mahmood, } \\
2009)^{29} \\
\end{array}$ & 2 & 2 & 0 & 0 & 0 & 6 & 6 & 6 & 0 & 22 \\
\hline $\begin{array}{c}\text { (O'Connor et } \\
\text { al., 2016) }\end{array}$ & 6 & 2 & 4 & 4 & 6 & 6 & 6 & 6 & 6 & 46 \\
\hline $\begin{array}{c}\text { (Falcoski et } \\
\text { al.2020) }\end{array}$ & 0 & 0 & 0 & 0 & 0 & 6 & 6 & 6 & 0 & 18 \\
\hline $\begin{array}{c}\text { (Akgul et al., } \\
2016 a)^{35} \\
\end{array}$ & 0 & 2 & 0 & 0 & 0 & 6 & 0 & 0 & 0 & 8 \\
\hline $\begin{array}{c}\text { (Akgul et al., } \\
2016 b)^{36} \\
\end{array}$ & 2 & 2 & 0 & 0 & 0 & 6 & 6 & 6 & 0 & 22 \\
\hline $\begin{array}{l}\text { (Nehring et } \\
\text { al., 2014) }\end{array}$ & 2 & 6 & 4 & 2 & 6 & 6 & 6 & 6 & 0 & 38 \\
\hline $\begin{array}{c}\text { (Neiderman } \\
\text { et al., } \\
2000)^{38} \\
\end{array}$ & 0 & 0 & 0 & 0 & 0 & 6 & 6 & 4 & 0 & 16 \\
\hline $\begin{array}{c}\text { (Robb et al., } \\
2002)^{39} \\
\end{array}$ & 4 & 6 & 4 & 4 & 0 & 6 & 6 & 6 & 0 & 36 \\
\hline $\begin{array}{c}\text { (Neiderman } \\
\text { et al., } \\
2001)^{40} \\
\end{array}$ & 4 & 2 & 0 & 0 & 0 & 6 & 0 & 0 & 0 & 12 \\
\hline $\begin{array}{l}\text { (Gusella et } \\
\text { al., 2017) }\end{array}$ & 2 & 2 & 0 & 0 & 0 & 6 & 6 & 6 & 0 & 22 \\
\hline $\begin{array}{l}\text { (Madden et } \\
\text { al., 2009) }\end{array}$ & 4 & 6 & 6 & 6 & 0 & 6 & 0 & 0 & 0 & 28 \\
\hline $\begin{array}{c}\text { (van Noort } \\
\text { et al., } \\
2018)^{43} \\
\end{array}$ & 4 & 6 & 4 & 4 & 0 & 6 & 6 & 6 & 0 & 36 \\
\hline $\begin{array}{c}\text { (Strik } \\
\text { Lievers et } \\
\text { al., 2009) } \\
\end{array}$ & 4 & 6 & 4 & 4 & 0 & 6 & 6 & 6 & 0 & 36 \\
\hline $\begin{array}{c}\text { (Halse et al., } \\
2005)^{45} \\
\end{array}$ & 4 & 2 & 2 & 2 & 0 & 6 & 6 & 6 & 0 & 28 \\
\hline $\begin{array}{l}\text { (Clausen et } \\
\text { al., 2018) }\end{array}$ & 4 & 6 & 6 & 6 & 2 & 6 & 6 & 6 & 0 & 42 \\
\hline $\begin{array}{l}\text { (Bayes and } \\
\text { Madden, } \\
2011)^{47}\end{array}$ & 0 & 2 & 2 & 0 & 0 & 6 & 2 & 4 & 0 & 16 \\
\hline $\begin{array}{l}\text { (Kodua et } \\
\text { al.2020) }\end{array}$ & 0 & 0 & 0 & 0 & 0 & 6 & 6 & 6 & 0 & 18 \\
\hline
\end{tabular}




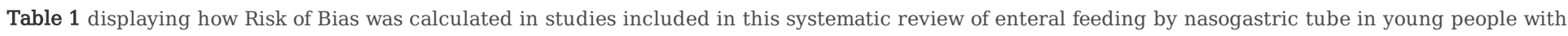

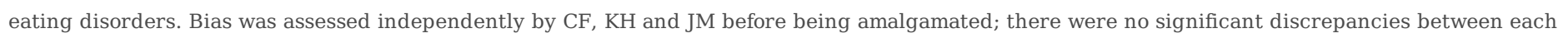

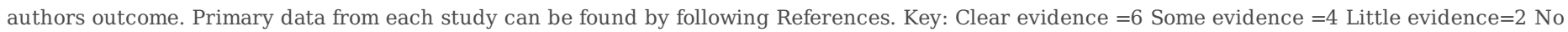
evidence $=0$.

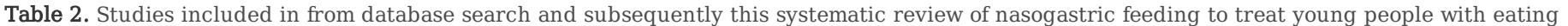
disorders. 


\begin{tabular}{|c|c|c|c|c|c|c|c|c|c|c|}
\hline$\underline{\text { References }}$ & $\underline{\text { Study Design }}$ & $\frac{\text { Country }}{\underline{\text { Set }}}$ & $\begin{array}{l}\underline{\text { Time }} \\
\underline{\text { Frame / }} \\
\underline{\text { Follow }} \\
\text { uppyears } \\
\text { (months) }\end{array}$ & $\frac{\underline{N \text { total }}}{(\underline{\text { Female }})}$ & $\begin{array}{c}\underline{\text { Agge }} \\
\text { Range } \\
\text { (years) }\end{array}$ & Setting. & $\underline{\text { Aims }}$ & $\begin{array}{l}\frac{\text { NG Primary } \perp}{\text { Secondary }} \\
\underline{\text { Outcome? }} \\
\text { (Reason for } \\
\frac{\text { Implementing }}{\underline{\text { NG })}}\end{array}$ & $\underline{\text { Main Outcomes }}$ & $\frac{\text { Risk of }}{\underline{\text { Bias }}}$ \\
\hline $\begin{array}{l}\text { Whitelaw et } \\
\text { al., } 2010^{9}\end{array}$ & $\begin{array}{l}\text { Cohort Study } \\
\text { (retrospective) }\end{array}$ & Australia & TF 1 & $\begin{array}{c}29 \\
\text { (not } \\
\text { stated) }\end{array}$ & $12-18$ & $\begin{array}{c}\text { Adolescent } \\
\text { Medical } \\
\text { Ward }\end{array}$ & $\begin{array}{l}\text { Assess whether } \\
\text { more aggressive } \\
\text { refeeding leaves } \\
\text { patients at } \\
\text { greater risk of } \\
\text { HP }\end{array}$ & $\begin{array}{l}\text { Secondary } \\
\text { (Inadequate } \\
\text { oral intake) }\end{array}$ & $\begin{array}{l}\text { HP associated with lower } \\
\text { \%IBW and lower number } \\
\text { of hospital admissions; } \\
15 \% \text { required NG feeding }\end{array}$ & Medium \\
\hline $\begin{array}{l}\text { Rocks et al., } \\
2014^{10}\end{array}$ & $\begin{array}{l}\text { Cross- } \\
\text { Sectional } \\
\text { Study } \\
\text { (prospective) }\end{array}$ & Australia & $\begin{array}{l}\mathrm{TF} \\
0(3)\end{array}$ & $\begin{array}{c}17 \\
(\mathrm{n} / \mathrm{a})\end{array}$ & N/A & $\begin{array}{l}\text { Variety of } \\
\text { Settings }\end{array}$ & $\begin{array}{c}\text { Describe } \\
\text { practices of } \\
\text { Australian } \\
\text { dietitians in } \\
\text { management of } \\
\text { AN }\end{array}$ & $\begin{array}{l}\text { Secondary } \\
\text { (Inadequate } \\
\text { oral intake) }\end{array}$ & $\begin{array}{l}\text { All dietitians stated OR } \\
\text { was offered first with } \\
\text { supplementation. } 82 \% \\
\text { recommended } \\
\text { implementing NG feeding } \\
\text { as part of re-feeding } \\
\text { process. }\end{array}$ & Medium \\
\hline $\begin{array}{l}\text { Maginot et } \\
\text { al., } 2017^{17}\end{array}$ & $\begin{array}{l}\text { Cohort Study } \\
\text { (retrospective) }\end{array}$ & USA & TF 1 & $\begin{array}{l}87 \\
(73)\end{array}$ & $8-20$ & $\begin{array}{c}\text { Medical } \\
\text { Behavioural } \\
\text { Unit }\end{array}$ & $\begin{array}{l}\text { Safety of higher } \\
\text { calorie } \\
\text { nutritional } \\
\text { rehabilitation } \\
\text { protocol (NRP) }\end{array}$ & $\begin{array}{l}\text { Secondary } \\
\text { (Inadequate } \\
\text { oral intake) }\end{array}$ & $\begin{array}{c}\text { Lower \%IBW on } \\
\text { admission more important } \\
\text { predictor of HP than } \\
\text { initial calories. } \\
\text { Malnourished patients } \\
\text { started on lower calories } \\
\text { more likely to have NG } \\
\text { tube. }\end{array}$ & Medium \\
\hline $\begin{array}{c}\text { Paccagnella } \\
\text { et al., } \\
2006^{20}\end{array}$ & $\begin{array}{l}\text { Cohort Study } \\
\text { (prospective) }\end{array}$ & Italy & TF 1 & $\begin{array}{l}24 \\
(24)\end{array}$ & $11-32$ & "Hospital" & $\begin{array}{l}\text { Define minimal } \\
\text { criteria for } \\
\text { "lifesaving" } \\
\text { treatment and } \\
\text { submit a patient } \\
\text { to NG }\end{array}$ & $\begin{array}{c}\text { Secondary } \\
\text { (medical } \\
\text { instability) }\end{array}$ & $\begin{array}{l}\text { Symptomatology } \\
\text { improved the day after } \\
\text { NG; is beneficial } \\
\text { especially when used for } \\
\text { life saving treatment } \\
\text { initially }\end{array}$ & Medium \\
\hline $\begin{array}{l}\text { Silber et al., } \\
\qquad 2004^{21}\end{array}$ & $\begin{array}{l}\text { Cohort Study } \\
\text { (retrospective) }\end{array}$ & USA & TF 10 & $\begin{array}{l}14 \\
(0)\end{array}$ & $12-18$ & $\begin{array}{c}\text { Adolescent } \\
\text { Inpatient } \\
\text { Unit }\end{array}$ & $\begin{array}{c}\text { Determine } \\
\text { outcomes of } \\
\text { supplementing } \\
\text { oral refeeding } \\
\text { with nocturnal } \\
\text { NG } \\
\text { supplementation }\end{array}$ & $\begin{array}{c}\text { Primary } \\
\text { (Routinely) }\end{array}$ & $\begin{array}{l}\text { Maximum kcals were } \\
\text { greater, weight achieved } \\
\text { at discharge greater in } \\
\text { treatment group } \\
\text { compared to oral } \\
\text { refeeding only }\end{array}$ & High \\
\hline $\begin{array}{l}\text { Madden et } \\
\text { al., } 2015^{22}\end{array}$ & $\begin{array}{c}\text { RCT } \\
\text { (prospective) }\end{array}$ & $\begin{array}{l}\text { Australia/ } \\
\text { USA }\end{array}$ & TF 3 & $\begin{array}{l}82 \\
(78)\end{array}$ & $12-18$ & $\begin{array}{c}\text { Paediatric } \\
\text { Medical } \\
\text { Ward }\end{array}$ & $\begin{array}{l}\text { Long term } \\
\text { outcomes of } \\
\text { treating to } \\
\text { restore weight } \\
\text { rather than just } \\
\text { to medically } \\
\text { stabilise }\end{array}$ & $\begin{array}{l}\text { Secondary } \\
\text { (Routinely) }\end{array}$ & $\begin{array}{l}\text { No difference in hospital } \\
\text { days used after initial } \\
\text { admission, however } \\
\text { therefore total fewer days } \\
\text { in hospital for MS. }\end{array}$ & Low \\
\hline $\begin{array}{l}\text { Agostino et } \\
\text { al., } 2013^{23}\end{array}$ & $\begin{array}{l}\text { Cohort Study } \\
\text { (retrospective) }\end{array}$ & Canada & $\begin{array}{l}\text { TF } 8 \\
\text { FU } \\
0(6)\end{array}$ & $\begin{array}{l}165 \\
(158)\end{array}$ & $10-18$ & $\begin{array}{c}\text { Paediatric } \\
\text { Medical } \\
\text { Ward }\end{array}$ & $\begin{array}{l}\text { Difference in } \\
\text { LOS between } \\
\text { adolescent ED } \\
\text { treated with } \\
\text { short-term } \\
\text { continuous NG } \\
\text { feeding vs. } \\
\text { managed with } \\
\text { lower calorie } \\
\text { meals }\end{array}$ & $\begin{array}{c}\text { Primary } \\
\text { (Routinely) }\end{array}$ & $\begin{array}{l}\text { LOS reduced in the NG- } \\
\text { fed cohort; No significant } \\
\text { difference in } \\
\text { complications or } \\
\text { electrolyte abnormalities } \\
\text { (90\% NG cohort received } \\
\text { prophylactic phosphate). }\end{array}$ & Medium \\
\hline $\begin{array}{l}\text { Parker et } \\
\text { al., } 2016^{24}\end{array}$ & $\begin{array}{l}\text { Cohort Study } \\
\text { (retrospective) }\end{array}$ & Australia & TF 3 & $\begin{array}{l}167 \\
(152)\end{array}$ & $14-19$ & $\begin{array}{l}\text { Adolescent } \\
\text { ED unit }\end{array}$ & $\begin{array}{l}\text { Weight gain and } \\
\text { complications } \\
\text { associated with } \\
\text { refeeding } \\
\text { prescribed } \\
\text { greater initial } \\
\text { calories }\end{array}$ & $\begin{array}{c}\text { Secondary } \\
\text { (Medical } \\
\text { instability) }\end{array}$ & $\begin{array}{l}\text { Mean starting intake was } \\
2611.7 \mathrm{kcal} / \text { day }(58.4 \\
\mathrm{kcal} / \mathrm{kg} \text { ) With inclusion of } \\
\text { phosphate } \\
\text { supplementation no } \\
\text { increased risk of RS. }\end{array}$ & Medium \\
\hline $\begin{array}{l}\text { Madden et } \\
\text { al., } 2015^{25}\end{array}$ & $\begin{array}{c}\text { RCT } \\
\text { (prospective) }\end{array}$ & Australia & $\begin{array}{l}\text { TF } \\
1(9)\end{array}$ & $\begin{array}{c}78 \\
(74)\end{array}$ & $12-18$ & $\begin{array}{l}\text { Paediatric } \\
\text { ED service }\end{array}$ & $\begin{array}{l}\text { More rapid } \\
\text { refeeding } \\
\text { protocol } \\
\text { promotes initial } \\
\text { weight recovery } \\
\text { and medical } \\
\text { stability. }\end{array}$ & $\begin{array}{c}\text { Primary } \\
\text { (Medical } \\
\text { instability) }\end{array}$ & $\begin{array}{l}\text { Adequate weight gain and } \\
\text { minimal adverse effects } \\
\text { were observed. All } \\
\text { patients gained weight in } \\
\text { week } 1 \text { with no cases of } \\
\text { HP or RS. }\end{array}$ & Low \\
\hline Kezelman & Cohort & Australia & TF $1(2)$ & 31 & $15-19$ & Specialist & Explore the & Secondary & All patients received NG & Medium \\
\hline
\end{tabular}




\begin{tabular}{|c|c|c|c|c|c|c|c|c|c|c|}
\hline $\begin{array}{c}\text { et al., } \\
2018^{26}\end{array}$ & (prospective) & & $\begin{array}{l}\text { FU 8-66 } \\
\text { days }\end{array}$ & (31) & & $\begin{array}{c}\text { ED } \\
\text { Adolescent } \\
\text { medical } \\
\text { ward }\end{array}$ & $\begin{array}{l}\text { relationship } \\
\text { between anxiety } \\
\text { and weight } \\
\text { restoration }\end{array}$ & $\begin{array}{c}\text { (Medical } \\
\text { instability) }\end{array}$ & $\begin{array}{l}\text { initially. No established } \\
\text { relationship between } \\
\text { changes in anxiety and } \\
\text { weight restoration. }\end{array}$ & \\
\hline $\begin{array}{c}\text { Fuller et al., } \\
2019^{27}\end{array}$ & $\begin{array}{l}\text { Cross- } \\
\text { Sectional } \\
\text { Study } \\
\text { (prospective) }\end{array}$ & $\begin{array}{c}\text { UK/ } \\
\text { Ireland }\end{array}$ & TF 1 & $\begin{array}{l}134 \\
(\mathrm{n} / \mathrm{a})\end{array}$ & $\mathrm{n} / \mathrm{a}$ & $\begin{array}{l}\text { Variety of } \\
\text { Settings }\end{array}$ & $\begin{array}{l}\text { Identify common } \\
\text { current practice } \\
\text { and if specialist } \\
\text { ED units are } \\
\text { managing AN } \\
\text { differently to } \\
\text { other inpatient } \\
\text { settings }\end{array}$ & $\begin{array}{l}\text { Primary } \\
\text { (Inadequate } \\
\text { oral intake) }\end{array}$ & $\begin{array}{l}\text { 43.3\% reported that they } \\
\text { were able to facilitate NG } \\
\text { feeding; } \\
79 \% \text { of units providing } \\
\text { NG feeding were able to } \\
\text { facilitate physical } \\
\text { interventions }\end{array}$ & Medium \\
\hline $\begin{array}{c}\text { Street et al. } \\
2016^{28}\end{array}$ & $\begin{array}{l}\text { Case Reports } \\
\text { (prospective) }\end{array}$ & England & $\begin{array}{l}\text { TF } 3 \\
\text { FU 1-2 }\end{array}$ & $\begin{array}{l}31 \\
(30)\end{array}$ & $10-17$ & $\begin{array}{l}\text { Paediatric } \\
\text { medical } \\
\text { ward }\end{array}$ & $\begin{array}{c}\text { Evaluate joint } \\
\text { care ED pathway } \\
\text { between } \\
\text { CAMHS and } \\
\text { paediatric wards }\end{array}$ & $\begin{array}{l}\text { Secondary } \\
\text { (Medical } \\
\text { Instability) }\end{array}$ & $\begin{array}{l}\text { Time-limited admissions } \\
\text { with boundaried-care } \\
\text { plans are easier to } \\
\text { manage and enjoyed } \\
\text { feeling supported by } \\
\text { CAMHS }\end{array}$ & High \\
\hline $\begin{array}{l}\text { Couturier } \\
\text { and } \\
\text { Mahmood, } \\
2009^{29}\end{array}$ & $\begin{array}{l}\text { Cohort Study } \\
\text { (retrospective) }\end{array}$ & Canada & $\begin{array}{l}\text { TF } 2 \\
\text { FU } 1\end{array}$ & $\begin{array}{l}21 \\
(19)\end{array}$ & $11-17$ & $\begin{array}{l}\text { Psychiatric } \\
\text { Inpatient } \\
\text { Unit }\end{array}$ & $\begin{array}{l}\text { Understand } \\
\text { whether } \\
\text { implementing } \\
\text { meal support } \\
\text { therapy reduced } \\
\text { need for NG }\end{array}$ & $\begin{array}{l}\text { Primary } \\
\text { (Inadequate } \\
\text { oral intake) }\end{array}$ & $\begin{array}{l}\text { Meal support therapy } \\
\text { reduces need for NGT } \\
(66.7 \% \text { to } 11.1 \% \text { after } \\
\text { implementation }(\mathrm{P}<0.02))\end{array}$ & Medium \\
\hline $\begin{array}{l}\text { Falcoski et } \\
\text { al.,202030 }\end{array}$ & $\begin{array}{l}\text { Case Series } \\
\text { (prospective) }\end{array}$ & UK & TF 1 & $\begin{array}{l}3 \\
(2)\end{array}$ & $11-14$ & $\begin{array}{l}\text { Specialist } \\
\text { ED unit }\end{array}$ & $\begin{array}{l}\text { Evaluate new } \\
\quad \text { dietetic } \\
\text { guidelines for } \\
\text { AN in clinical } \\
\text { practice }\end{array}$ & $\begin{array}{c}\text { Primary } \\
\text { (variable) }\end{array}$ & $\begin{array}{c}\text { Different use of NGT } \\
\text { feeding to suit individual; } \\
\text { use of continuous and } \\
\text { single bolus feeds via NG } \\
\text { tube }\end{array}$ & High \\
\hline $\begin{array}{l}\text { O'Connor et } \\
\text { al., } 2016^{31}\end{array}$ & $\begin{array}{c}\mathrm{RCT} \\
\text { (prospective) }\end{array}$ & UK & TF 2 & $\begin{array}{c}36 \\
(34)\end{array}$ & $10-16$ & $\begin{array}{l}\text { Paediatric } \\
\text { medical } \\
\text { Ward }\end{array}$ & $\begin{array}{l}\text { Higher calorie } \\
\text { refeeding } \\
\text { anthropometric } \\
\text { outcomes, } \\
\text { cardiac and } \\
\text { biochemical } \\
\text { markers }\end{array}$ & $\begin{array}{l}\text { Secondary } \\
\text { (Inadequate } \\
\text { oral intake) }\end{array}$ & $\begin{array}{c}\text { Adolescents on high } \\
\text { energy intake had greater } \\
\text { weight gain. } 11 \% \\
\text { participants required NG } \\
\text { feeding for failure to meet } \\
\quad 80 \% \text { oral intake. }\end{array}$ & Low \\
\hline $\begin{array}{l}\text { Akgul et al., } \\
2016^{35}\end{array}$ & $\begin{array}{l}\text { Case Series } \\
\text { (retrospective) }\end{array}$ & Turkey & TF 4 & $\begin{array}{l}13 \\
(0)\end{array}$ & $11-17$ & $\begin{array}{l}\text { Paediatric } \\
\text { Medical } \\
\text { Ward }\end{array}$ & $\begin{array}{c}\text { Describe } \\
\text { medical, } \\
\text { psychiatric, } \\
\text { cultural features } \\
\text { of adolescent } \\
\text { males with an } \\
\text { ED }\end{array}$ & $\begin{array}{l}\text { Secondary } \\
\text { (Inadequate } \\
\text { oral intake) }\end{array}$ & $\begin{array}{l}\text { Male:female increased } \\
(3.6: 1 \mathrm{~F}: \mathrm{M}) ; 2 / 13 \text { given } \\
\text { NG due to refusal to eat } \\
\text { in hospital }\end{array}$ & High \\
\hline $\begin{array}{l}\text { Akgul et al., } \\
2016^{36}\end{array}$ & $\begin{array}{l}\text { Cohort Study } \\
\text { (retrospective) }\end{array}$ & Turkey & TF 6 & $\begin{array}{l}35 \\
(28)\end{array}$ & $11-17$ & $\begin{array}{l}\text { Paediatric } \\
\text { Medical } \\
\text { Ward }\end{array}$ & $\begin{array}{c}\text { Explore } \\
\text { paediatric unit } \\
\text { where no } \\
\text { specific ED unit } \\
\text { for to discuss } \\
\text { refeeding } \\
\text { approaches and } \\
\text { goals for } \\
\text { discharge }\end{array}$ & $\begin{array}{c}\text { Primary } \\
\text { (variable) }\end{array}$ & $\begin{array}{c}\text { Paediatric ward is } \\
\text { acceptable where } \\
\text { specialist ED inpatient } \\
\text { unit not viable; specialist } \\
\text { unit better however } \\
\text { limited resources }\end{array}$ & Medium \\
\hline $\begin{array}{l}\text { Nehring et } \\
\text { al., } 2014^{37}\end{array}$ & $\begin{array}{l}\text { Cohort Study } \\
\text { (retrospective) }\end{array}$ & Germany & $\begin{array}{l}\text { TF } 10 \\
\text { FU } \\
1-12\end{array}$ & $\begin{array}{c}208 \\
(208)\end{array}$ & $12-18$ & $\begin{array}{l}\text { Psychiatric } \\
\text { Inpatient } \\
\text { Unit }\end{array}$ & $\begin{array}{l}\text { Short-term and } \\
\text { long-term } \\
\text { outcomes of } \\
\text { treating with EN } \\
\text { compared to no } \\
\text { EN }\end{array}$ & $\begin{array}{c}\text { Primary } \\
\text { (not } \\
\text { discussed) }\end{array}$ & $\begin{array}{c}\text { No significant difference } \\
\text { in recovery following EN; } \\
34 \% \text { had EN during at } \\
\text { least } 1 \text { hospitalisation }\end{array}$ & Medium \\
\hline $\begin{array}{c}\text { Neiderman } \\
\text { et al., } \\
2004^{38}\end{array}$ & $\begin{array}{l}\text { Case reports } \\
\text { (prospective) }\end{array}$ & England & FU 1 & $\begin{array}{c}4 \\
(3)\end{array}$ & $13-16$ & $\begin{array}{c}\text { Adolescent } \\
\text { Unit }\end{array}$ & $\begin{array}{c}\text { Report of } \\
\text { gastrostomy or } \\
\text { jejunostomy use } \\
\text { in } 4 \text { cases of AN }\end{array}$ & $\begin{array}{l}\text { Secondary } \\
\text { (Medical } \\
\text { instability) }\end{array}$ & $\begin{array}{l}\text { 4/4 patients required NG } \\
\text { feeding and progressed to } \\
\text { require } \\
\text { gastrostomy/jejuonostomy } \\
\text { due to complications }\end{array}$ & High \\
\hline $\begin{array}{c}\text { Robb et al., } \\
2002^{39}\end{array}$ & $\begin{array}{l}\text { Cohort Study } \\
\text { (retrospective) }\end{array}$ & USA & TF 6 & $\begin{array}{l}100 \\
(100)\end{array}$ & $12-18$ & $\begin{array}{l}\text { Paediatric } \\
\text { Medical } \\
\text { Ward }\end{array}$ & $\begin{array}{l}\text { Compare short- } \\
\text { term outcomes } \\
\text { of oral vs. } \\
\text { supplemental } \\
\text { nocturnal } \\
\text { nasogastric } \\
\text { refeeding }\end{array}$ & $\begin{array}{c}\text { Primary } \\
\text { (Routinely) }\end{array}$ & $\begin{array}{l}\text { Weight gain significantly } \\
\text { increased in treatment } \\
\text { group, no significant } \\
\text { difference in length of } \\
\text { hospital stay }\end{array}$ & Medium \\
\hline Neiderman & Cross- & UK & $\mathrm{TF}$ & $58(21$ & Patients & Paediatric & Analyse patient & Primary & $71 \%$ patients said they did & High \\
\hline
\end{tabular}




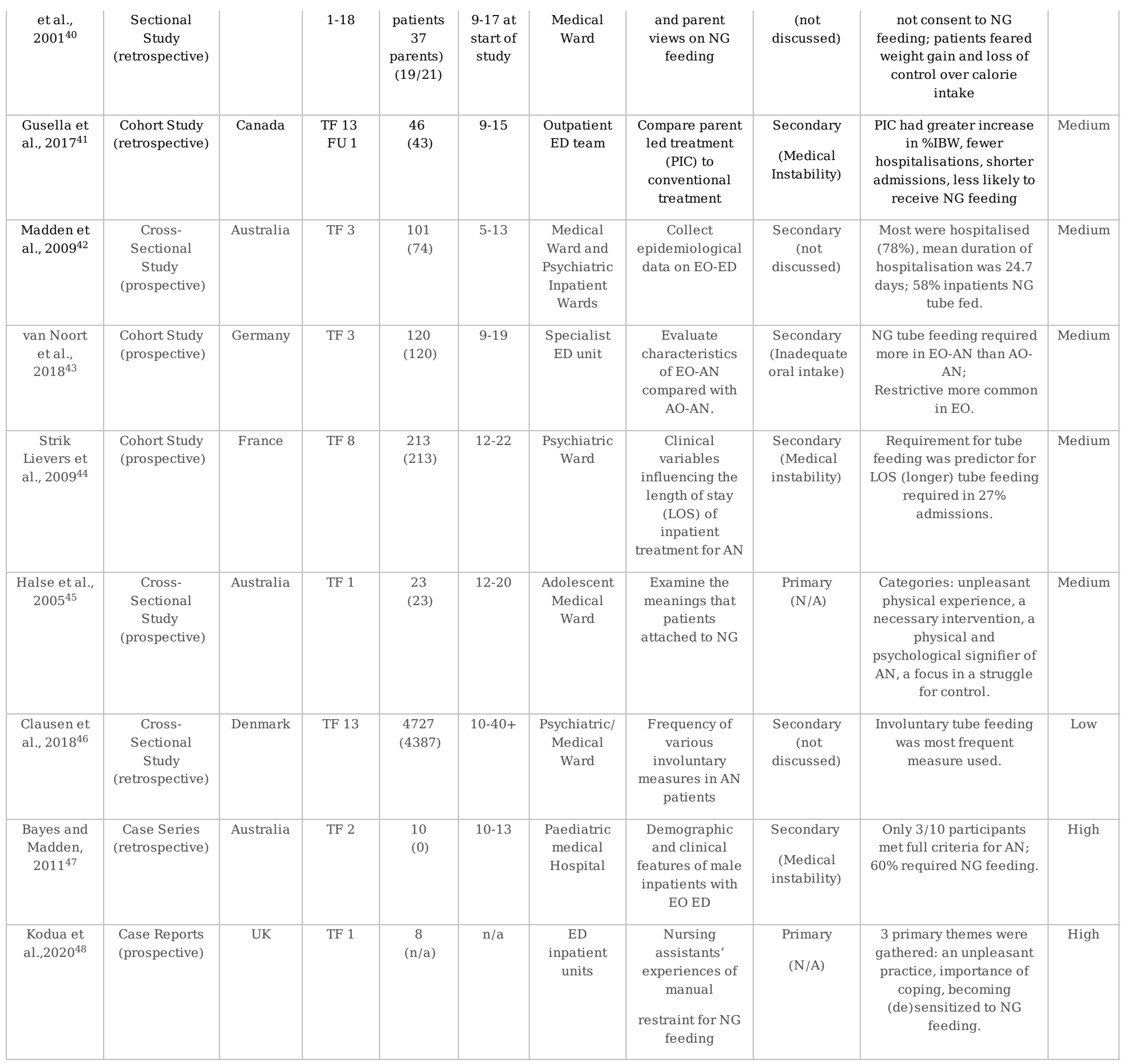

Table 2 displaying all 29 studies included in this systematic review. Data included in this table is: reference, type of study, country of setting, time frame and follow up in years (months) where information has been given, number of participants (with number of females), main aims of the study, setting, reason for implementation of NG feeding, risk of bias, and primary outcomes from each study. Primary data from studies can be found by following the reference. Key: $\mathrm{N}$ = number of participants; FU = follow up; TF = Time Frame; NG = Nasogastric (Feeding); LOS = Length of Stay; ED = Eating disorder; EO = Early onset; $\mathrm{AN}=$ Anorexia nervosa; $\mathrm{RS}=$ refeeding syndrome; \% IBW = percentage ideal bodyweight; $\mathrm{HP}=$ hypophosphataemia; $\mathrm{OR}=$ oral refeeding; $\mathrm{RCT}=$ randomised control trial.

Table 3 Nasogastric Feeding Protocol (in Relation to Setting) and Complications Identified in Studies Included in this Systematic Review. 


\begin{tabular}{|c|c|c|c|c|}
\hline $\begin{array}{l}\text { Study } \\
\text { (Bias risk) }\end{array}$ & Setting & NG Feeding Type & Feeding Regime & Complications \\
\hline $\begin{array}{l}\text { Whitelaw } \\
\text { et al, } 2010^{9} \\
\text { (Medium) }\end{array}$ & $\begin{array}{l}\text { Medical } \\
\text { Ward }\end{array}$ & $\begin{array}{l}\text { Oral intake supplemented with bolus NG feeding if oral } \\
\text { RDI not met }\end{array}$ & Minimum of $1900 \mathrm{kcals}$ on day 1 and increased by $300 \mathrm{kcal}$ per day & $\begin{array}{l}38 \% \text { developed HP. HP was associated } \\
\text { with lower \%IBW on admission }\end{array}$ \\
\hline $\begin{array}{l}\text { Rocks et al, } \\
2014^{10} \\
\text { (Medium) }\end{array}$ & $\begin{array}{l}\text { MH and } \\
\text { Medical } \\
\text { Wards }\end{array}$ & $\begin{array}{l}\text { High energy supplements and NG feeds were commonly } \\
\text { used to meet RDI. }\end{array}$ & $\begin{array}{l}\text { The initial calorie intake recommended was between } 800-1750 \mathrm{kcals} \\
\text { advised by dietitians in Australia. }\end{array}$ & Not discussed \\
\hline $\begin{array}{l}\text { Maginot et } \\
\text { al, } 2017^{17} \\
\text { (Medium) }\end{array}$ & $\begin{array}{l}\text { Medical } \\
\text { Ward }\end{array}$ & $\begin{array}{l}\text { Bolus NG feeds supplemental to oral intake if RDI not } \\
\text { met }\end{array}$ & $\begin{array}{l}\text { Average of } 1185 \mathrm{kcal} \text { average which increased to an average of } 1781 \mathrm{kcals} \\
\text { (range } 1500-3000 \mathrm{kcals} \text { ) }\end{array}$ & $\begin{array}{l}\text { Hypomagnaemia and HP reported, HP was } \\
\text { more likely in those under } 80 \% \% \text { IBW }\end{array}$ \\
\hline $\begin{array}{l}\text { Paccagnella } \\
\text { et al, } \\
2006^{20} \\
\text { (Medium) }\end{array}$ & Unknown & Continuous NG feeding until medically stable & $15.9-19.7 \mathrm{kcal} / \mathrm{kg} /$ day; increased to $30 \mathrm{kcal} / \mathrm{kg} /$ day after 24 hours. & $\begin{array}{l}\text { No patient developed nausea, vomiting, or } \\
\text { worsened abdominal symptoms; } 2 \\
\text { developed lower limb oedema despite slow } \\
\text { infusion. }\end{array}$ \\
\hline $\begin{array}{l}\text { Silber et al, } \\
2004^{21} \\
\text { (High) }\end{array}$ & MH Ward & $\begin{array}{l}\text { Nocturnal NG feeding to supplement daily oral intake vs } \\
\text { oral refeeding only (control) }\end{array}$ & $\begin{array}{l}\text { Nocturnal NG feeding regime patients were prescribed calories } \\
\text { individually (max } 4350 \mathrm{kcal} \text { ) and } 3400 \text { in the oral refeeding group } \\
\text { (control). }\end{array}$ & Epistaxis, nasal irritation. \\
\hline $\begin{array}{l}\text { Madden et } \\
\text { al, } 2015^{22} \\
\text { (Low) }\end{array}$ & $\begin{array}{l}\text { Medical } \\
\text { Ward }\end{array}$ & $\begin{array}{l}\text { Continuous NG feeding until medically stable; followed } \\
\text { by oral intake with supplemental noctumal NG feeding } \\
\text { until biomarkers stabilised. }\end{array}$ & $\begin{array}{l}\text { NG feeding continuously for 1-2 days. Weight gain aim for } 1 \mathrm{~kg} \text { per week. } \\
\text { Weaning to oral diet occurred as soon as medically stable - average } 14 \\
\text { days on NG with feed of } 2400-3000 \mathrm{kcal} \text { per day }\end{array}$ & Not discussed \\
\hline $\begin{array}{l}\text { Agostino et } \\
\text { al, } 2013^{23} \\
\text { (Medium) }\end{array}$ & $\begin{array}{l}\text { Medical } \\
\text { Ward }\end{array}$ & $\begin{array}{l}\text { Continuous NG feeding at a higher calorie intake } \\
\text { compared to lower calorie standard oral intake. }\end{array}$ & $\begin{array}{l}\text { Starting range for NG cohort } 1200-2000 \mathrm{kcal} \text { increased by } 200 \mathrm{kcal} / \text { day } \\
\text { vs. } 800-1200 \mathrm{kcal} \text { increased by } 150 \mathrm{kcal} / \text { day (oral cohort). NG fed for } 7 \\
\text { days then weaned over } 3 \text { days with kcal via NG reducing as meals } \\
\text { replaced }\end{array}$ & $\begin{array}{l}\text { Oral cohort } 51 \% \text { lost weight initially } \\
\text { compared to } 6 \% \text { in the NG high kcal } \\
\text { cohort. Hypokalaemia (although both } \\
\text { cases were abusing laxatives), HP. }\end{array}$ \\
\hline $\begin{array}{l}\text { Parker et } \\
\text { al, } 2016^{24} \\
\text { (Medium) }\end{array}$ & MH Ward & $\begin{array}{l}\text { Continuous NG feeding or combination of oral intake } \\
\text { with supplemental overnight NG feeding, or oral intake } \\
\text { alone. }\end{array}$ & Start feed $2400 \mathrm{kcal}$ increasing to $2400-3400 \mathrm{kcal} /$ day at $100 \mathrm{ml}$ per hour & $\begin{array}{l}\text { Peripheral oedema ( } 4 \%) \text {, hypomagnaemia } \\
(7 \%) \text {, hypokalaemia }(2 \%) \text {, HP ( } 1 \%) \text {. No } \\
\text { incidence of RS or delirium. }\end{array}$ \\
\hline $\begin{array}{l}\text { Madden et } \\
\text { al, } 2015^{25} \\
\text { (Low) }\end{array}$ & $\begin{array}{l}\text { Medical } \\
\text { Ward }\end{array}$ & $\begin{array}{l}\text { Continuous NG feeding until medically stable; followed } \\
\text { by oral intake with supplemental noctumal NG feeding } \\
\text { until biomarkers stabilised. Average \%IBW at initiation } \\
\text { was } 78\end{array}$ & $\begin{array}{l}2400-3000 \mathrm{kcal} \text { to meet weekly target of weight gain of } 1 \mathrm{~kg} / \text { week. In the } \\
\text { first week average weight gain was } 2.79 \mathrm{~kg} \text {. }\end{array}$ & Stated no patients developed RS or HP \\
\hline $\begin{array}{l}\text { Kezelman } \\
\text { et al } \\
2018^{26}\end{array}$ & $\begin{array}{l}\text { Medical } \\
\text { Ward }\end{array}$ & $\begin{array}{l}\text { Continuous NG until medically stable followed by oral } \\
\text { intake supplemented by nocturnal NG feeding }\end{array}$ & $\begin{array}{l}2400 \mathrm{kcal} / \text { day for } 24 \mathrm{hrs} \text { or until medically stable, changed to oral diet } \\
\text { starting } \sim 1800 \mathrm{kcal} \text { increasing to a maximum of } 3800 \mathrm{kcal} \text { with nocturnal } \\
\text { NG top up feeds stopped when BMI }>18.5\end{array}$ & Not discussed \\
\hline $\begin{array}{l}\text { Fuller et al, } \\
2019^{27} \\
\text { (Medium) }\end{array}$ & MH Ward & $\begin{array}{l}\text { Results from questionnaire showed non-specialist } \\
\text { psychiatric units gave } 73 \% \text { NG as syringe bolus, } 27 \% \\
\text { as enteral pump. Specialist ED units gave } 85 \% \text { as } \\
\text { syringe bolus, } 15 \% \text { as enteral pump. }\end{array}$ & $\begin{array}{l}\text { Volume of bolus feed ranged from } 330-1000 \mathrm{ml} \text { average } 564 \mathrm{ml} \text { per feed. } \\
\text { Bolus feed time ranged between } 10-40 \text { minutes average being } 20 \\
\text { minutes. If delivered by pump it was }>1 \text { hour. }\end{array}$ & Not discussed \\
\hline $\begin{array}{l}\text { Street et al, } \\
2016^{28} \\
\text { (High) }\end{array}$ & $\begin{array}{l}\text { Medical } \\
\text { Ward }\end{array}$ & Bolus feeds & NG feeds were higher in calories than meals to motivate eating. & Not discussed \\
\hline $\begin{array}{l}\text { Couturier } \\
\text { and } \\
\text { Mahmood, } \\
2009^{29}\end{array}$ & MH Ward & $\begin{array}{l}\text { Bolus NG feeding if patient failed to gain } 1 \mathrm{~kg} / \text { week or } \\
\text { acute refusal of meals }\end{array}$ & Not discussed & $\begin{array}{l}\text { Nausea, odynophagia, self-harm, epistaxis, } \\
\text { anxiety, sadness, } 38.4 \% \text { patients } \\
\text { experienced mild HP }\end{array}$ \\
\hline
\end{tabular}




\begin{tabular}{|c|c|c|c|c|}
\hline (Medium) & & & & \\
\hline $\begin{array}{l}\text { Falcoski et } \\
\text { al, } 2020^{30} \\
\text { (High) }\end{array}$ & MH Ward & $\begin{array}{l}\text { Oral calories supplemented with bolus NG feeds, single } \\
\text { bolus of high calorie NG feeding, and } 3 \text { smaller single } \\
\text { boluses. }\end{array}$ & $\begin{array}{l}\text { Starting feed } 1200 \mathrm{kcal} \text {, increased by } 200 \mathrm{kcal} \text { per day to } 2000 \mathrm{kcal} .1 \mathrm{NG} \\
\text { feed per day under restraint. Also described } 1 \text { bolus feed of } 2000 \mathrm{kcal} \\
\text { due to no oral intake for } 20 \text { hours }\end{array}$ & $\begin{array}{l}\text { Distress described during the procedure } \\
\text { requiring Lorazepam }\end{array}$ \\
\hline $\begin{array}{l}\text { O’Connor } \\
\text { et al, } \\
2016^{31} \\
\text { (Low) }\end{array}$ & $\begin{array}{l}\text { Medical } \\
\text { Ward }\end{array}$ & $\begin{array}{l}\text { Supplemental bolus NG feeding if patients failed to } \\
\text { meet } 80 \% \text { RDI. At initiation \%IBW was }<78 \%\end{array}$ & Compared $500 \mathrm{kcal}$ starting diet with $1200 \mathrm{kcal}$ & HP (28\%) \\
\hline $\begin{array}{l}\text { Akgul et al, } \\
2016^{35} \\
\text { (High) }\end{array}$ & MH Ward & Not discussed & Initiated at $750 \mathrm{kcal}$ per day and increased by $220 \mathrm{kcal}$ per day & $\begin{array}{l}\text { HP described in } 2 \text { cases (unable to } \\
\text { determine if this was in those requiring } \\
\text { NG) }\end{array}$ \\
\hline $\begin{array}{l}\text { Akgul et al, } \\
2016^{36} \\
\text { (Medium) }\end{array}$ & $\begin{array}{l}\text { Medical } \\
\text { Ward }\end{array}$ & $\begin{array}{l}\text { Not discussed, the majority of young people were under } \\
80 \% \% \text { IBW }\end{array}$ & Started on an average of $975 \mathrm{kcal}$. Average duration of NG was 2.5 days & $\begin{array}{l}\text { HP described in } 2 \text { cases (unable to } \\
\text { determine if this was in those requiring } \\
\text { NG) }\end{array}$ \\
\hline $\begin{array}{l}\text { Robb et al, } \\
2002^{39} \\
\text { (Medium) }\end{array}$ & $\begin{array}{l}\text { Medical } \\
\text { Ward }\end{array}$ & Nocturnal NG feeding to supplement daily oral intake & $\begin{array}{l}\text { Starting NG feed at } 600 \mathrm{kcal} \text {. Ratio oral kcal to NG was approximately } \\
2: 1 . \text { NG feed via pump at } 40 \mathrm{cc} \text { per hour for } 4 \text { hours then } 60 \mathrm{cc} \text { per hour } \\
\text { for } 4 \text { hours. Increases to } 1200 \mathrm{kcal} \text { NG feed over } 3 \text { nights. Weaned when } \\
\text { the young person is } 95 \% \mathrm{IBW} \text {. }\end{array}$ & $\begin{array}{l}\text { Epistaxis }(11.5 \%) \text {, anxiety }(3.8 \%) \text { treated } \\
\text { with Lorazepam, removal of NG tube } \\
(5.8 \%) \text {, nasal irritation }(28.8 \%)\end{array}$ \\
\hline $\begin{array}{l}\text { Neiderman } \\
\text { et al, } \\
2001^{40} \\
\text { (High) }\end{array}$ & $\begin{array}{l}\text { Medical } \\
\text { Ward }\end{array}$ & $\mathrm{N} / \mathrm{A}$ & Calories individualised and increased to gain of $1-2 \mathrm{~kg} /$ week. & Removal of tube (55\%). \\
\hline
\end{tabular}

Table 3 displaying different refeeding methods, regimes and complications evaluated by studies in this review. Key: BMI Body Mass Index; NG nasogastric; MH mental health; RDI recommended daily intake; HP hypophosphataemia; RS refeeding syndrome; \%IBW percentage ideal bodyweight.

\section{Figures}

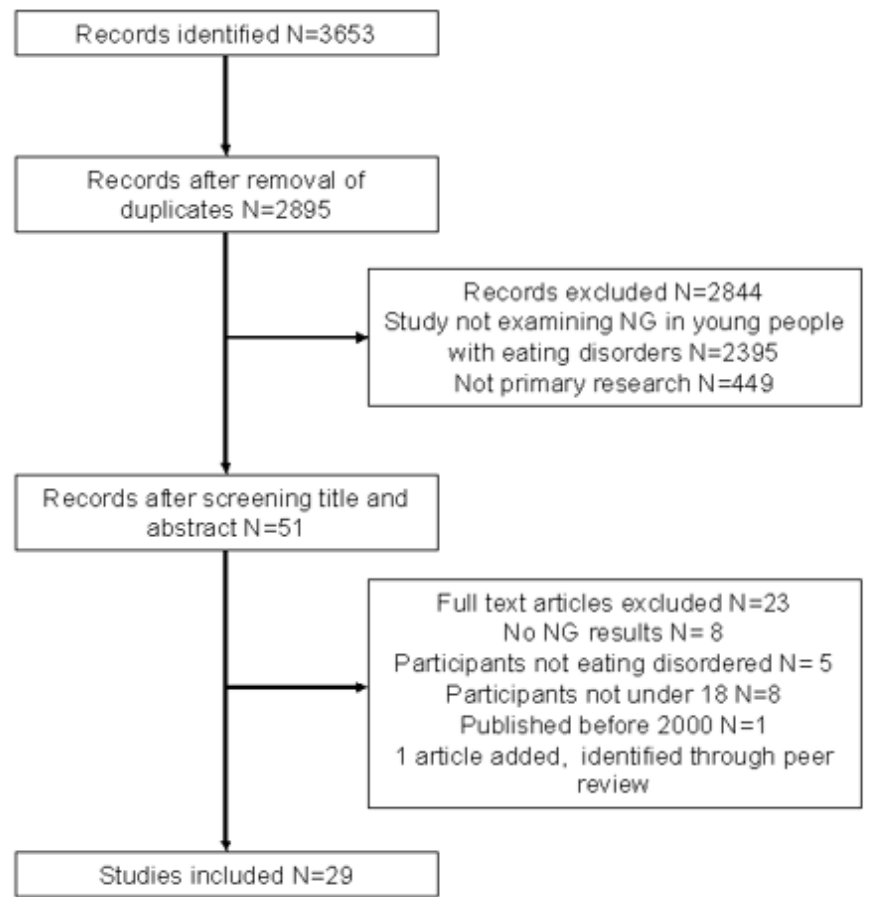

Figure 1 
PRISMA Flowchart Figure displaying PRISMA flowchart of methodology utilised to search databases for this systematic review of enteral feeding in young people with restrictive eating disorders. 